Of these three fascinating books on virtual reality, Mirror Worlds, by David Gelernter, associate professor of computer science at Yale University, is the most unusual and perhaps most speculative. He doesn't so much focus on the traditional notions of virtual reality and its hardware as on the concept of a 'mirror world' - a huge true-to-life mirror image of corporations and ideas trapped inside a computer. For example, using a desktop computer and computer graphics, a hospital administrator might 'wander' through an entire medical complex. The hospital mirror world has a software version of every patient, doctor, bed and room and every important abstract entity: drug orders, cash in the bank and so on. Most of Gelernter's book describes how users will consult the mirror world like an encyclopaedia. $\mathrm{He}$ points out that many computer programs today run continuously and that this will become our basic way of thinking about programs: as continuously running factories, information refineries, operating around the clock gathering information from vast public repositories and chattering together. The basic idea is that mirror worlds can and will exist:

The real software revolution won't have much to do with fancy robots, computers in education, canned "multimedia" hype or the other hot topics that dominate this month's hit parade. It will center instead on software that steps over the crucial boundary between private and public.

In Glimpses of Heaven, Visions of Hell, Barrie Sherman and Phil Judkins take the reader on a comprehensive and equally absorbing tour of the political, economic, social, moral, psychological and religious aspects of virtual reality. In the authors' view, the implications will be far-reaching: sex will never be the same and virtual reality will almost certainly be exploited by criminals.

By contrast, Benjamin Woolley, author of Virtual Worlds, focuses on the dramatic intellectual and cultural upheavals that gave birth to virtual reality, and the people who have promoted it. Some may find his style irritating, however:

The gloomy postmodernists think that rationalist values of truth and certainty are being destroyed. The upbeat, bullshitting virtual realists think they can make something better, that dreams can truly be turned into reality .... But is reality really dead? Are we obliged to leave it to the virtual realist to create another one for us? Must we sink into postmodern autism?

But there is much else of substance in the book for those who shy away from this kind of wild philosophizing.

Clifford A. Pickover is at the IBM Thomas J. Watson Research Center, Yorktown Heights, New York 10598, USA.

\section{Wire taps}

\section{Orlando Belpaese}

The Bohr-Einstein Transcripts. Edited by T. J. Gschäftlhuber. Midgley-Cideryard: 1993. Pp. 137. \$14.95 (pbk).

THE demise of the art of letter writing with the advent of the telephone is often regretted, especially by historians robbed of valuable primary material. Had Darwin had an early telephone, we would have been deprived of his ruminations on the development of the theory of evolution, which can be gleaned

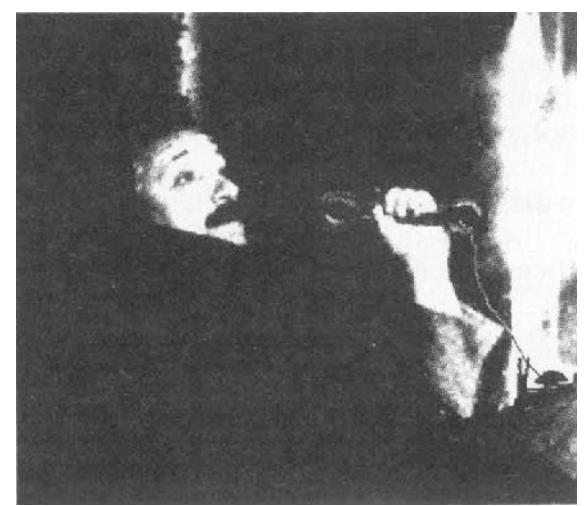

Einstein - ringing true?

from his published correspondence.

The most celebrated scientific debate of this century was that between Einstein and Bohr, conducted mostly by letter and at conferences, but also in the Physical Review and other learned journals. Not only have Einstein's difficulties with quantum mechanics, despite his seminal part in its invention, cast a long shadow over the development of physics in the latter part of this century; they have also kept an army of historians employed, poring over the protagonists' extensive correspondence.

Curiously, the Bell Telephone Company helped preserve another small corner of the quantum debate, now presented in this handsome but diminutive booklet prepared by Jerry Gschäftlhuber. At about the time Einstein arrived at Princeton, in 1933, Bell was working on a prototype telephonic recording machine, the Mnemophone. A wire recorder that could be attached to a telephone, this was in many ways a precursor to the modern answerphone (it is often forgotten that many devices, and prototypical facsimile transmitters, were tested before the turn of the century).

As part of a promotional effort, Bell made gifts of a few Mnemophones to celebrities of the time - President Roosevelt, Sinclair Lewis, George Gershwin, Charles Lindberg and, as the ultimate symbol of the new science, Einstein. Einstein was naturally en- chanted by this machine - not merely an ex-patent clerk, he had also dabbled in inventions himself, and had patents on, among other things, a hearing aid and a noiseless refrigerator. He recorded few of his telephone conversations with the Bell machine, which was evidently unreliable (according to Gschäflthuber, Einstein can be heard cursing and even striking the malfunctioning device at times), but he clearly treasured his occasional transatlantic discussions with Bohr enough for these to form the major part of the surviving magnetic archive.

Gschäftlhuber has faithfully transcribed and translated these conversations (the originals, of course, were in German), released to him by the Einstein Archive at Princeton University, in full, including even the everyday trivia of all phone calls - talk of the weather, the Princeton Tigers' recent games, vacation preparations and so on. Inevitably, the quantum debate has none of the coherence evident in the Bohr-Einstein correspondence (recorded by Bohr in Albert Einstein: Philosopher-Scientist, Tudor, New York, 1949), but key ideas are instantly recognizable.

More significantly, historians of science have already been excited by hints of a lost paper (Über die Elektrodynamik und die fermische Theorie der hochenenergischen Betastrahlen) tying in Fermi's new theory of nuclear $\beta$-decay with electrodynamics. Possibly a precursor to the electroweak theory of the 1960 s and $70 \mathrm{~s}$, the paper might give the lie to the idea that Einstein's late work was blocked by an obsession with unifying electromagnetism only with gravity. From the conversations, Bohr evidently read, disliked and possibly killed the ideas. The hope is that, although no version of this paper survives among Einstein's possessions, a draft may still be in Bohr's archives, waiting to be found.

Immaculately prepared and annotated, and with rare photographs of both scientists, this book will not change our view of the developing philosophy of quantum mechanics; but it casts the debate into a charmingly humane light. Many will be amused by the appendix, containing recorded conversations with several Hollywood starlets, major and minor, of the day, which make a delightful addition to Einstein's famous collection of autographs. And historians who fear that the arrival of mobile phones will rob us even of the fruits of answerphone messages can take heart from recent revelations of misdeeds involving British royalty.

Orlando Belpaese is in the School of History and Philosophy of Science, Tara Community College, Atlanta, Georgia 010493, USA. 